\title{
RAT DOLAZI DUGO. \\ PISANJE ODJEKA ŠUMADIJE O RATU \\ TOKOM 1941. GODINE
}

\section{Željko Milanović}

UDK: 070(497.11Kragujevac)“1941“

Izvorni znanstveni članak

Sažetak: U periodu od 1936. do 1941. godine u Kragujecu je uređivan i štampan list Odjek Šmadije, samoreprezentovan kao „nezavisan informativni list za društvena pitanja”. Njegov urednik, Milovan R. Pantović, štampaće list neujednačenim ritmom koji je zavisio prvenstveno od novčanih sredstava. List je negovao krajnje neobičnu koncepciju koja, između ostalog, spaja neprekidne apele za pomaganje siromašnima i gladnima, vesti o nemoralu pojedinaca, zvanična saopštenja policijskih i vojnih vlasti. Rad istražuje pisanje lista tokom 1941. godine, odnosno način na koji je javnost Kragujevca mogla da prati približavanje rata, kao i literarnu reprezentaciju rada ovog lista u romanu Sluge hirovitog lučonoše Mirka Demića. Novinarski jedinstvena koncepcija sučeljava se sa savremenom literarnom vizijom da bi potvrdila naše nedoumice o sudbini jednog intelektualca i jednog grada, u prošlosti i sadašnjosti.

Ključne reči: rat, novinarstvo, Odjek Šumadije, intelektualac, Milovan R. Pantović, Mirko Demić

Milovan R. Pantović Gandi je bio vlasnik, urednik i autor najvećeg broja priloga u kragujevačkom nedeljniku Odjek Šumadije, koji je izlazio u periodu od 5. maja 1936. do 8. aprila 1941. godine. Pantovićeva (auto)biografija je oskudna - o njoj jedino svedoči Odjek Šumadije. I površan uvid u pisanje Odjeka Šumadije zbunjuje i nameće pitanje: da li je Milovan R. Pantović intelektualac? Ako je odgovor potvrdan, o kakvom intelektualcu je onda reč? Međutim, ako nije, ovim bi radom bila promašena tema simpozijuma na kome je predstavljen ovaj rad. Neopravdano bi bilo reći unapred da Pantović jeste intelektualac - nedopustivo je uraditi ono što se najčešće radi - samouverenost imenovanja ne obećava da postoji ono što je imenovano.

Uobičajena je tvrdnja da se pojam (kritičkog) intelektualca rodio u zapadnoj Evropi sa aferom Drajfus, odnosno da ovaj pojam svoj značaj dobija sa Zolinim tekstom Optužujem. Dubravka Stojanović kaže da je pojam intelektualac preuzet od ruske emigracije kao i da je „posle Zoline 'optužnice', postao sinonim za opoziciju i društvenu disidenciju, u ime novih 
moralnih vrednosti". ${ }^{1}$ Dubravka Stojanović insistira na onome što se iznova prepoznaje kao jedino bitno u određivanju ovog pojma: „inteligencija je ili kritička ili nije inteligencija”.

Govoriti o intelektualcu je nemoguće bez sagledavanja višestrukih procesa njegovog (samo)oblikovanja (ideološkog ili utopijskog). Mogućnost da govorimo o intelektualcu nastaje tek kada prepoznamo da se pojedinac oslobodio mnogobrojnih društvenih sila koje teže njegovom oblikovanju. Samooblikovanje intelektualca je proces čiji uspesi zavise od dve suprotstavljene moći. Prva od njih je javno predstavljena u očekivanjima za govorom i ponašanjem u skladu sa vrednostima koje učvršćuju ideologiju moći. Druga bi mogla da bude obeležena nasleđem, uzorom koji stiče slobodu da misli i dela bez obzira na pritiske, prepreke ili opasnosti - uzorom koji ne mora da bude oličen u određenoj ličnosti, pokretu ili epohi već može da bude i uzor slobode da se teži izmeni odnosa u svetu kako bi Drugi (religijski, politički, rodno, ekonomski, nacionalno ili na bilo koji drugi način markiran) bio oslobođen svoje razlike koja se jedino prepoznaje da bi umanjila njegov značaj, a u krajnjim oblicima krize - i da bi ga uništila. U svakom slučaju, intelektualac teži preoblikovanju sveta bez obzira na veličinu prostora koji zahvata i uspehe koje postiže, pa čak i bez obzira na paradoksalnost svojih rezultata.

Paradoksalnost rezultata koje postiže intelektualac tematski je prisutna i u delima Vladana Desnice ali i trajno obeležava napore Milovana R. Pantovića. Desnica u romanu Proljeća Ivana Galeba prati odjeke Drajfusove afere, čak i njene moguće posledice - jedan od bezbrojnih načina da se intelektualac pojavi. U Proljećima Ivana Galeba, glavni junak se seća kako je njegov deda sa svojim prijateljima raspravljao o lokalnim i svetskim događajima, o vestima koje je donosio Lojdov parobrod na stranicama Glasa gradanina. Dedu i prijatelje zagrevaju diskusije o različitim stvarima ali i oko „protestnih brzojava u Dreyfussovoj aferi”. ${ }^{3}$ Njihove "pobune i zanosi, protesti i indignacije” umiru „među zidovima te naše blagovaonice, pod kapom plavičastih oblaka dima - ukoliko nisu mogli da se pretoče u tekst jedne brzojavke, bilo pozdravne bilo protestne”. ${ }^{4}$ Desničin junak to vreme imenuje „zlatnim dobom čovečanstva”, vremenom u kome „sve što se događalo, događalo se daleko”. ${ }^{5} \mathrm{I}$ Milovan R. Pantović deluje kao Galebov deda i njegovo društvo, ali za razliku od Desničinog junaka, urednik kragujevačkog nedeljnika više ne živi u zlatnom dobu čovečanstva: ono što se njemu događa nezaustavljivo postaje deo istorije, narativ koji neki drugi parobrod odnosi kao vest nekim drugim starcima, ako takvi još uvek postoje $s$ obzirom na razmere rata. Pantović o distanci ne može da misli, svako njegovo delovanje je nužno pred haosom sveta.

Neke od Desničinih pripovedaka (Božićna priča, Pred zoru, Susjedi) kao i roman Zimsko ljetovanje problematizuju ponašanje pojedinca koji nije direktni učesnik rata. Desnicu interesuje pojedinac u vremenima pred rat, tokom i posle rata. U Božićnoj priči junak je mobilisani novinar u vreme koje je „sasvim mirisalo na rat", ${ }^{6}$ dok pripovetka Susjedi prati ponašanje porodice posle rata pred strahom da će biti kažnjena zbog stvaranja zaliha hrane i ponašanje pojedinca kome je ideja o nabavci frižidera linija koja uspostavlja kontinuitet života. U ovim Desničinim prozama prepoznaje se atmosfera o kojoj svedoči i Pantovićev nedeljnik.

Dubravka STOJANOVIĆ, „Tadić i inteligencija” (pescanik.net/2012/05/tadic-i-inteligencija).

Isto.

Vladan DESNICA, Proljeća Ivana Galeba (igre proljeća i smrti), Beograd 1960., 41.

Isto.

Isto, 42.

Vladan DESNICA, Olupine na suncu, Zagreb 1952., 211. 


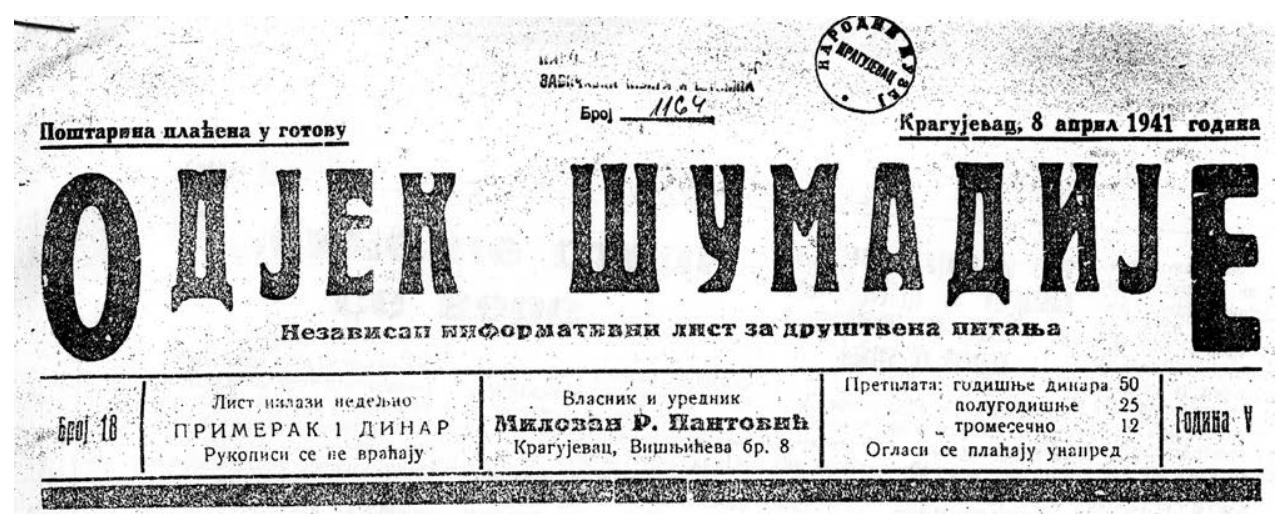

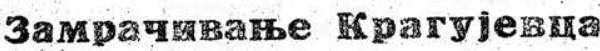

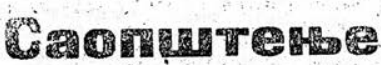

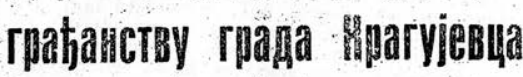

Саопштава се грађанству града Крагујевца да од дана обнародовања ове наредбе у листу „Одјек Шумадије“ има се стриктно придржавати свих упутстава датих оА стране овог одбора у погледу замрачивава својих ставова и сзојих мокала.

Замрачнвање има одпочети одмах од данас па за све време ноһи, од првог мрака до сванућа.

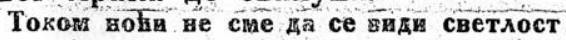
нв из qијег става, те је у овом смислу неоп-
Патријарх Гаврияо у име сто уједињен и окупљен Светог Архијерејског Са- око свога младог Краља, бора и у име своје поши- мушки и достојанствено, а љаоџе очински отпоздрав- у духу својих вековних траља и благосиља и са топ- Аиција, чувати и бранити лим молитвама Свемогу⿰ем гравице, част, слободу Богу гаји непоколебиву на. граниџе, част и слободу југословенски парод, чвр- љевине Југославије.

\section{Hнвео "Iраљ Петар II}

Витешка Шумадија и овога рало одржати у црквеној пор пута доказала је да слободу ти. Служили су сви овд. свецени више и изнад свега. Ње- штеници. Многн су плакали од на омладина и авога пута до- радости кад се у молитвама казала је да је достојна својнх спомињало име Јубљеног Краказала је да је достојна својнх спомињало име љубљеног Крада је у њој крв хероја, који су говорно је врло лепо архијеза слободу приносили животе рејски намесник протојереј $r$. своје са песмом, са клицањем. Дим. Стевановић. После блаНаје. са песмом, са клицањем, Дим. Стевановић. После блаПетар II узео власт у своје ру. трг. позвао је присутне да сө

Slika 1. Naslovnica zadnjeg broja kragujevačkih Odjeka Šumadije od 8. travnja 1941. godine, dva dana nakon početka rata u Jugoslaviji

Ako Desničina proza može da svedoči o jednom vremenu, možda se može pitati da li do sada bezbroj puta citirana rečenica koja je postala poetički marker njegove proze - „Da ja pišem knjige, u tim se knjigama ne bi događalo ama baš ništa"7 - odnosno rečenica koja sledi za njom - „Pričao bih i pričao što mi god na milu pamet padne, povjeravao čitaocu, iz retka u redak, sve što mi prođe mišlju i dušom" ${ }^{8}$ - mogu da se razumeju ne kao otklon od fabuliranja i njegove linearnosti, odnosno ne kao pripovedačeva zaokupljenost esejizacijom građe, već kao pokušaj da se ukaže na značaj slobodnog razumevanja sveta, razumevanja van oblikotvornih zamisli maskiranih ideologija jednog društva, odnosno na značaj pokušaja da se pod maskom izostajanja događaja jače istaknu upravo oni događaji rođeni u stvarnosti a o kojima nije poželjno govoriti u svetu rastuće neslobode??

Odjek Šumadije deluje kao list u kome njegov vlasnik i urednik piše i objavljuje zaista ono što mu na pamet padne - od denunciranja svakog nemorala (bračne prevare, krađe,

\footnotetext{
V. DESNICA, Proljeća Ivana Galeba, 107.

Isto.

Zaista, u romanu Proljeća Ivana Galeba junak ne samo da je okupiran svojom prošlošću već posmatra i događaje koji itekako problematizuju istorijsko vreme. Različite epizode, izdvojimo samo one najmarkantnije, o studentu Radivoju ili generalovom boravku u bolnici, svedoče o tome.
} 
ponašanje omladine, tuče, nemara poštanskih radnika, neizmirivanja duga za troškove pretplate na Odjek), preko neprekidnih apela za pomoć siromašnima i gladnima, kritike pozorišta, samoreklamerstva pa sve do zahteva da građani između nekoliko kratkih vesti razmisle o tome šta će činiti kad dođe do napada iz vazduha. Jednostavnije rečeno, Odjek Šumadije je list lokalnog karaktera u kome nema vesti iz sveta ali u kome itekako odjekuje buka sveta koja će, kad postane snažna i bliska, i zaustaviti izlaženje lista a njegovog urednika učiniti žrtvom.

U sumi pisanja Odjeka Šumadije u poslednjoj godini izlaženja uočljiva su četiri ključna tematska interesa: pozivanje na brigu o siromašnima i gladnima (od iznošenja preciznih podataka o gladnim porodicama, pozdravljanje svake humanitarne akcije, ukazivanje na mogućnosti zloupotrebe u humanitarnim organizacijama do spiskova darodavaca u različitim prilikama), beleženje kulturnih dešavanja (proslave Svetog Save, gostovanja muzičkih i pozorišnih grupa, apel za izgradnju zgrade pozorišta, interesovanje za sudbinu legata, dešavanja u i oko bioskopa...), ukazivanje na najrazličitije vrste nemorala (u okvirima porodice kao i u odnosu pojedinca prema vrednostima braka, poštenja, časnog obavljanja najrazličitijih poslova). Nad ova tri tematska kruga natkriljuje se i četvrti koji je prisutan i u svima njima - beleženje simptoma nadolazećeg rata, od nacionalnog zanosa do straha od slabljenja vojne moći i govora o opasnosti od stranaca do nebrige za ponašanje kad dođe do napada.

Kako je Odjek Šumadije bio jedini kragujevački list tokom 1941. godine, u njemu su objavljivana i zvanična saopštenja i naredbe vlasti. Upravo je glas vlasti rečitije govorio u dolasku rata od bilo kakvog izveštavanja o njemu. List već u drugom broju u 1941. godini (7. januar) donosi čestitku ministra vojnog u kojoj se napominje da se od vojnika zahteva veliki napor zbog situacije u svetu. Objavljeno je i saopštenje Poreske uprave o potrebi plaćanja doprinosa za fond Narodne odbrane. Od ovog broja započeće i objavljivanje spiskova vojnih obaveznika kojima se ne zna mesto boravka - oni se pozivaju da se odmah jave vojnim vlastima. Četvrti broj (19. januar) donosi saopštenje Mesnog odbora za zaštitu od napada iz vazduha o naredbi da se dejstvuje protiv sve učestalijih nedozvoljenih preleta stranih aviona. U ovom broju se nalazi i vest o dovoljnim količinama šećera na tržištu ali i o nameri vlasti da kazni svako stvaranje zaliha (neretko stvarnost nekih Desničinih pripovedaka je i stvarnost Odjeka Šumadije). U devetom broju (23. februar) gradska policija izdaje naredbu o preduzimanju mera pasivne zaštite od napada iz vazduha (kopanje rovovskih zaklona u dvorištima, tečajevi i vežbe za građane). Naredni brojevi Odjeka pokazuju intenzivnije prisustvo vlasti u nagoveštajima rata. Tako se u desetom broju (2. mart) nalazi naredba o ponašanju građana i ustanova tokom vežbi za odbranu od vazdušnih napada, a jedanaesti broj (5. mart) na prvoj strani donosi saopštenje odbora za pasivnu zaštitu i kratko uputstvo o ponašanju u slučaju napada. 9. marta Odjek donosi Cvetkovićevu i Mačekovu izjavu o vladinim državnim interesima a 23. marta naredbu o obaveznom davanju otiska svake pisaće mašine u gradu! 27. marta izlazi vanredno izdanje na samo jednoj strani u kome se Kragujevčani obaveštavaju da je Petar II preuzeo kraljevsku vlast (u prethodnom broju, u preporuci knjige o Petru II rečeno je da će on kraljevsku vlast preuzeti tek 6. septembra). Pretposlednji broj Odjeka (6. april) donosi ponovo saopštenje Mesnog odbora za zaštitu od napada iz vazduha o neophodnosti da poslodavci upućuju svoje radnike na tečajeve zaštite, obaveštenje Jugoslovenske unije za zaštitu dece o planu evakuacije dece mlađe od 14 godina i poziv Crvenog krsta svim učenicima sa bolničkim tečajem da se jave radi dobijanja (ratnog) rasporeda. Poslednji broj Odjeka izlazi 8. aprila i razlikuje se od pretposlednjeg samo po tome što umesto teksta „Svesni smo i spremni” donosi naredbu o zamračivanju grada. 
Paralelno sa frekventnim oglašavanjem vlasti, Odjek svedoči da život koji i pored toga što miriše na rat i dalje teče - možda je najupečatljivi primer naslovna strana devetog broja na kojoj se paralelno nalaze naredba policije i tekst o sudbini biblioteke profesora Jovana Đ. Mirkovića. Međutim, u mnogobrojnim tekstovima uočljiva je sve veća blizina rata. Odjek u nekoliko navrata piše o problemima snabdevanja grada životnim namirnicama i neprekidnom rastu njihovih cena, smanjenju kvaliteta hleba, špekulacijama u nabavci brašna kao i o pokušajima da se ovi problemi reše samoorganizovanjem radničkih zadruga, zajmovima gradske vlasti, humanitarnim prilozima i stvaranjem odbora za aprovizaciju. U prvom broju u 1941. godini prikazana je i zbirka pesama Bitoljske rane Obrada Vučetina, čija je namera da mladima pokaže put stradanja za Jugoslaviju na način koji su to činili njihovi preci. Pred pozorište se postavlja poseban zadatak da prikazuje nacionalna i istorijska dela koja će imati prosvetni i socijalni smisao ali i književne vrednosti. Muzičko društvo iz Novog Sada gostuje u godini kada „u svetu besni pustoš rata, kada se nad zapaljenom Evropom i ostalim kontinentima viju crni oblaci”. ${ }^{10}$ Godina koja je prošla ocenjuje se kao godina promena, naročito u Evropi, promena koje nisu završene i koje će biti nastavljene i sa većom žestinom. Na Svetosavskoj proslavi biće rečeno da danas „topovi grme na sve strane oko nas. Padaju i mali i veliki. Još će mnogi pasti. Biće mnogo veće nedaće i strahote. Mi moramo da se osposobimo za život i da budemo onaj junak koji pada i ne kaže jaoj". ${ }^{11}$

U najrazličitijim tekstovima prisutan je odjek rata. Kragujevac je predstavljen kao radničko naselje u kome uglavnom živi sirotinja - polovina dnevnice je dovoljna tek za polovinu hleba čija je težina sve manja i manja a kvalitet sve lošiji. Svima je teško pa čak i gradska opština skraćuje radno vreme zbog uštede drva i osvetljenja, dešavaju se i samoubistva zbog bede, različita društva otkazuju zabave zbog „opšte situacije koja vlada u svetu”, ${ }^{12}$ čak i mrtvi osećaju da je život poskupeo - kandila će žmirkati zbog visoke cene zejtina. Da su vojne vežbe učestale svedoče obaveštenja zubara, lekara i advokata da su se vratili ili da tek odlaze, kao i tekst protesta protiv dugotrajnog zadržavanja čoveka koji živi samo sa bolesnom majkom.

U atmosferi nadolazećeg rata raste i ksenofobija. ${ }^{13}$ Odjek se pita da li je „,lasnik bioskopa Pivnica g. Jaroslav Fafonka, milioner, bio na vežbi i da li će i na njega red doći? Da li je obaveznik naše vojske ili koje druge?" ${ }^{14}$ Omladina se upozorava da plaćenici i izdajnici vrebaju, zamera se strancima koji "pokazuju tendencije i zauzimaju stav", ${ }^{15}$ traži se rešavanje pitanja državljanstva stranaca u Kragujevcu, osuđuje se izvoz robe preko Maribora u Nemačku kao i pozajmica ureda za osiguranje radnika data Hrvatskoj banovini. Sa druge strane, slavi se snaga jugoslovenske vojske, polažu se nade u dolazak Petra II, insistira se na religioznosti i veruje se da su Srbi „prekaljen narod koji je izrazito ratnički, uskočke, hajdučke rase” koja neće biti zbunjena događajima koji dolaze jer u poređenju sa drugim rasama ima ,jaču snagu moralnog otpora". ${ }^{16}$

10 Б. А, „Гостовање национацног музичког певачког друштва из Новог Сада у Крагујевцу“, Одјек IIyмaдије (Крагујевац), br. 6, 2. 2. 1941., 1.

11 П. „Прослава св. Саве у школи 'Краља Петра ИИ', Одјек Шумадије (Крагујевац), br. 7, 9. 2. 1941., 2.

12 “Једно саопштење”, Одјек Шумадије (Крагујевац), br. 4, 19. 11. 1941., 3.

13 „Internacionalna svila se prilikom svakog većeg iskušenja odbacuje, podređujući joj tople i nacionalne gunjeve”. (Mirko DEMIĆ, Sluge hirovitog lučonoše (roman u nastajanju), Zrenjanin 2006., 157.)

14 „Једно отворено питање”, Одјек ШІммадије (Крагујевац), br. 7, 9. 2. 1941., 2.

5 „Онима који нису поданици Краьевине Југославије”, Одјек Шумадије (Крагујевац), br. 14, 23. 3. $1941 ., 1$.

16 „Око евакуације и моралног отпора становништва на случај рата“, Одјек ШІммадие (Крагујевац), br. $14,23$. 3. 1941., 1 . 
Kao logična posledica dugogodišnjeg upozoravanja na najrazličitije poroke koji slabe vojnu spremnost naroda (alkohol, kocka i blud nanose štetu odbrambenoj moći zemlje isto kao i činjenica da fudbaleri dobijaju udarce i tako postaju nesposobni za borbu, tuče troše narodnu energiju podjednako kao i gazde koje teraju učenike zanata i poslugu da radi previše), u pretposlednjem broju Odjeka Milovan R. Pantović (uveren da aktuelni događaji uništavaju čitave narode ali i da je „srpstvo demodirana stvar”), najavljuje pokretanje časopisa Srpska gruda kome će jedini cilj da budi kulturni i nacionalni preporod.

Pantovićeva misija spasavanja sveta počiva naizgled na izboru protivrečnih ideoloških koncepta: hrišćanskog milosrđa, radničkog zadrugarstva i rastuće nacionalističke ksenofobije kojom se sa približavanjem rata sve više udaljava od oduševljenog zagovornika jugoslovenstva (sa porastom straha od ugroženosti i nacionalizam je snažniji - Odjek nagoveštava preobražaj u Srpsku grudu). Ideološki i utopijski koncepti koje Pantović sledi predstavljaju samo prividno paradoksalne odgovore na sveobuhvatnu krizu kojoj je jedini javni svedok: strah od neizbežne katastrofe ga vodi ka traženju rešenja koja bi bila pouzdan odgovor na glad, nestašice i rat koji se oseća svuda u gradu.

Urednik Odjeka Šumadije nije samo njegov glavni junak već je i glavni junak romana Mirka Demića Sluge hirovitog lučonoše u kome jedan drugi novinar, Jovan Kanela, pokušava da rekonstruiše Pantovićev život, njegove večite neuspehe u popravljanju sveta. Kanela piše reportažu o malverzacijama srpskih lokalnih komandanata tokom rata u Hrvatskoj, malverzacijama koje su maskirane vojnim tajnama i nacionalnim potrebama. Vojnici bez oznaka odvešće Kanelu na saslušanje i vratiti ga u svet uz upozorenje da pazi šta piše. Kanela dolazi kao izbeglica u Kragujevac. Kad pronađe izdanja Odjeka, pokušava da piše o njegovom uredniku. I Kanela će kao i Gandi dobijati batine na ulicama Kragujevca - njegovo pisanje ga odvodi u smrt: tokom bombardovanja 1999. godine ubijaju ga uz pitanje zašto i dalje piše onako kako piše.

Potreba Milovana R. Pantovića da promeni svet „po sopstvenom podobiju samo je povećavala otpor istog tog sveta prema promeni"17 - krajnji otpor sveta prema promeni zavšava ratom, Pantovićevim konačnim nestankom najverovatnije u masovnim streljanjima 1941. godine kao i opisanom Kanelinom smrću. Demić Pantovića vidi kao junaka dramatičnih gestova, sklonog insceniranju skandala, pisanju pisama podrške samom sebi, paranoičnog junaka koji oko sebe seje nelagodu - kao karnevalsku pojavu u predvečerje rata. Ali, sa jedne strane, Pantović je „omražen od većine sugrađana, a sa druge - obožavan od onih neuglednih, poniženih i odbačenih”, „istovremeno pljuvan i celivan, ismejavan i rado viđen, živeo je svoje dane dokazujući da čoveka čovekom čini spremnost da drugome bude na usluzi; bezuslovno, konstantno, uporno". ${ }^{18}$

Da li je onda M. Pantović intelektualac ili je reč o avanturisti čiji sukobi sa svetom imaju skrivene lične motive? Demić u svom romanu odgovara na ovo pitanje govoreći o Pantoviću čije su izjave samo naoko banalne i opštepoznate ali ni jedna od njih nije laž: „On nije mudrovao, već - podsećao!"19

Jovan Kanela, kad u Demićevom romanu počne da piše o Pantoviću, „uviđa kako sve češće počinje da ne razlučuje činjenice vezane za sudbine svojih junaka i situacija iz sopstve-

\footnotetext{
17 M. DEMIĆ, Sluge hirovitog lučonoše (roman u nastajanju), 30.

18 Isto, 171.

$19 \quad$ Isto, 173.
} 
ne biografije". ${ }^{20}$ Kao i njegov junak, sam pripovedač romana o Kaneli i Pantoviću rezonuje da „ovim se svetom kao ogromni gmazovi valjaju priče koje jedna drugu gutaju, i u tom uzajamnom proždiranju - pretiču preko svakog ljudskog veka i natkriljuju svaku pojedinačnu sudbinu”. ${ }^{21}$ Milovan R. Pantović i njegov uzor Mahatma Gandi kao i naš savremenik iz fikcije Jovan Kanela i njegov tvorac Mirko Demić, istovremeno kroz dva diskursa - novinarski i književni - u prošlosti i sadašnjosti svedoče o istom podjednakom snagom i istinitošću, dokazujući uzaludnost svake rasprave o potrebi kritike, otvorene ili dobro maskirane, upućene svetu u vremenima koja su daleko od zlatnih.

Odjek Šumadije jedini je žurnalistički svedok života Kragujevca nekoliko godina pred rat. Život grada u perspektivi Odjeka obeležen je osećajem propadanja, bliskog nestajanja tokom dugog dolaženja rata. Uredničko fokusiranje na malog i bednog čoveka kome treba pomoći, kao i na onog ko bi morao da brine o njemu a to ne čini, sa protokom vremena nije slabilo, kolebalo se, posustajalo ili menjalo svoj vrednosni registar. Rat, kome Odjek (naziv časopisa kao da je osmišljen da nam i danas pomaže da lakše razumemo svet reprezentovan u njemu) pripisuje totalitarne ciljeve može se pobediti samo „totalitarnom odbranom ugroženih”. ${ }^{22}$ Ovakva zamisao, objavljena na stranicama Odjeka, pokazaće se neostvarivom ali, videli smo u Demićevom romanu, svet nije prestao na isti način da sanja o takvoj mogućnosti ali i različitim načinima da tu mogućnost realizuje.

\section{Cos}

\section{THE WAR APPROACHES SLOWLY. What WAS WRITTEN ABOUT THE WAR IN ODJEK ŠUMADIJE IN}

\section{I94I}

Between 1936 and 1941, Odjek Šumadije, a magazine which described itself as "an independent, informative magazine dealing with social issues" was edited and published in Kragujevac. Its editor, Milovan R. Pantović, published the magazine with a dynamics dictated primarily by the availability of financial resources. The concept of the magazine was quite unusual, as it was pleading continuously for the necessity to help the poor and hungry, while publishing news on the immorality of individuals, as well as official statements given by the police and military authorities.

This paper deals with what was written in Odjek Šmadije during 1941, specifically, with the way the general public in Kragujevac was informed of the approaching of war and with the literary depiction of the magazine's activities in a novel by Mirko Demić, Sluge hirovitog lučonoše.

The editorial practice of the magazine and its key topics (the care of the poor and the hungry, culture, immorality and the imminent war) has its fictional parallels in the works of Vladan Desnica, specifically, in the atmosphere of war clearly implied in Desnica's short stories, in the hero's reflections on poetics and in his proclivity to writing down his every thought. Odjek Šumadije is a testing ground where the editor Milovan R. Pantović conducts his own mission of saving the world, a mission which appears to be based on a selection of seemingly contradictory ideological concepts: Christian charity, workers' cooperatives and growing nationalist xenophobia which, as

Isto, 27.

Isto, 7.

22 Чела Н. ПЕШИЋ, „ВазАушни рат и учешће омладине у рату односно у заштити од напаАа из ваздуха“, Одјек Шумадије (Крагујевац), br. 11, 5. 3. 1941., 2. 
the war approaches, causes him to stray from the Yugoslav idea of which he used to be an enthusiastic advocate. Not only is the editor of Odjek Šmadije its protagonist, but he is also the main character in Mirko Demićs aforementioned novel in which another journalist, Jovan Kanela, is trying to reconstruct Pantovićs life. Kanela writes a newspaper story on the misconduct of some local Serbian military commanders during the war in Croatia, then comes to Kragujevac as a refugee, where he reconstructs Pantović's life, gets beaten up because of his views, and is eventually murdered, during the bombing of 1999, while being asked why he still writes the way he writes. A unique journalistic concept is placed in juxtaposition with a contemporary literary vision to resolve our doubts as to the fate of an intellectual and a town in the past and the present.

Keywords: war, journalism, Odjek Šumadije, intellectual, Milovan R. Pantović, Mirko Demić

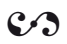

\section{Literatura}

Mirko DEMIĆ, Sluge hirovitog lučonoše (roman u nastajanju), Zrenjanin 2006.

Vladan DESNICA, Olupine na suncu, Zagreb 1952.

Vladan DESNICA, Proljeća Ivana Galeba (igre proljeća i smrti), Beograd 1960.

Одјек Шумадије (Крагујевац), 5/1941., br.1-18.

Dubravka STOJANOVIĆ, „Tadić i inteligencija” (pescanik.net/2012/05/tadic-i-inteligencija). 